The Tasmanian electoral roll trial in the 2002 ATSIC elections

\title{
W. Sanders
}

No. 245/2003

ISSN 1036-1774

ISBN 0731556208

Will Sanders is Fellow, Centre for Aboriginal Economic Policy Research, The Australian National University. 



\section{Table of Contents}

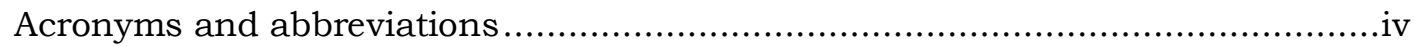

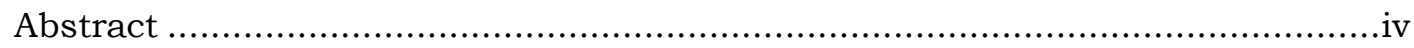

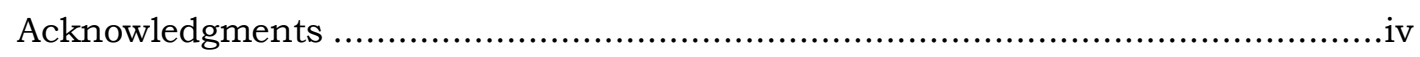

Introduction

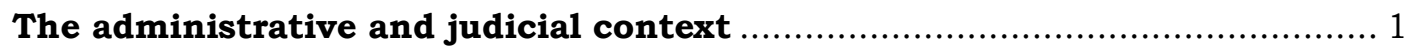

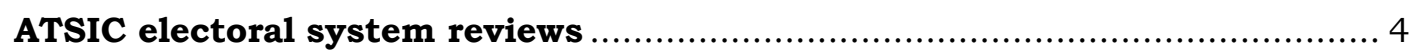

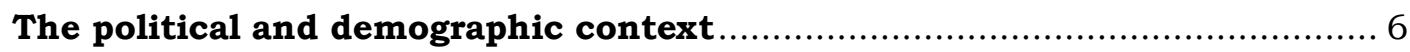

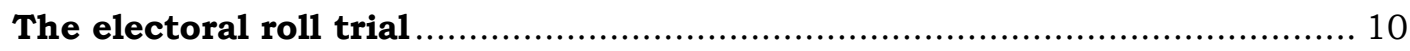

Lessons and options for the future .................................................... 14

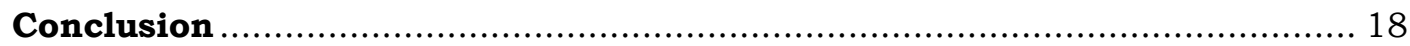

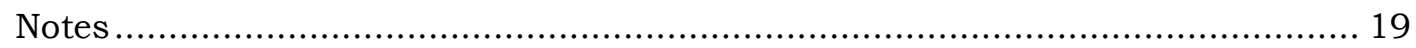

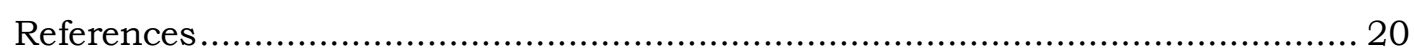

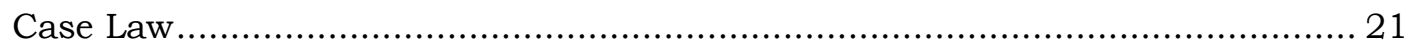

\section{Tables}

Table 1. Census counts and intercensal growth rates of people identifying as Aboriginal or Torres Strait Islander in Tasmania and the rest of Australia, 1971-2001 


\title{
Acronyms and abbreviations
}

$\begin{array}{ll}\text { AAT } & \text { Administrative Appeals Tribunal (Commonwealth) } \\ \text { AEC } & \text { Australian Electoral Commission } \\ \text { ANU } & \text { The Australian National University } \\ \text { ATSIC } & \text { Aboriginal and Torres Strait Islander Commission } \\ \text { CAEPR } & \text { Centre for Aboriginal Economic Policy Research } \\ \text { CER } & \text { Commonwealth Electoral Roll } \\ \text { FCA } & \text { Federal Court of Australia } \\ \text { IIAC } & \text { Independent Indigenous Advisory Committee } \\ \text { TAC } & \text { Tasmanian Aboriginal Centre } \\ \text { TASSC } & \text { Tasmanian Supreme Court }\end{array}$

\begin{abstract}
ATSIC elections since 1990 have used the Commonwealth Electoral Roll as a large, under-specified list of potential voters. Dissatisfaction with this arrangement within the Tasmanian Aboriginal community led to a trial roll of Indigenous electors being drawn up for the 2002 ATSIC elections in that State. This paper discusses a number of contexts in which this trial was developed. It also recounts the experience of the trial itself, which did not work out as successfully as had been hoped by those who had promoted it. Finally it looks at lessons from the trial and options for the future.
\end{abstract}

\section{Acknowledgments}

Caroline Joske and her colleagues in the ATSIC electoral unit encouraged me to undertake this study and provided me with much information. Paul Anderson at the Australian Electoral Commission also assisted with information. Jon Altman, Bill Gray, Fiona Hamilton, John Taylor and Maggie Walter provided useful feedback on various drafts, and Frances Morphy undertook her usual sterling task of final editing. Wendy Forster prepared the final layout. 


\section{Introduction}

Elections for the Commonwealth-created Aboriginal and Torres Strait Islander Commission (ATSIC) have been held every three years since 1990. They have been administered by the Australian Electoral Commission (AEC) using the Commonwealth Electoral Roll (CER) as a large 'under-specified' list of potential voters, since the CER does not specifically identify Aboriginal or Torres Strait Islander enrollees. As a result, all voting in past ATSIC elections has been 'declaration' voting - where the voter declares their 'Indigeneity', or 'right to vote', at the same time as voting - and all candidates declare their Indigeneity on nomination forms. These declarations are, through various mechanisms, subject to verification and challenge. Declarations have, in the past, been challenged most frequently and concertedly in Tasmania. As a consequence, an alternative administrative arrangement was trialled in Tasmania in 2002 in which an attempt was made, prior to the election, to draw up an Indigenous subset of the CER as an electoral roll for that State. The trial was, however, in the judgment of those who had promoted it, not as successful as had been hoped. So, what lay behind the trial? What went wrong from the perspective of those who had promoted it? And what are the lessons and options for the future?

This paper first explores the administrative and judicial contexts in which the Tasmanian electoral roll trial was undertaken. It then examines past ATSIC electoral system reviews and the broader demographic and political contexts. All of these contexts are complex and somewhat tangential, but some appreciation of them is necessary in order to fully understand the trial itself. The paper then recounts the actual experience of the electoral roll trial, before, in its final section, exploring lessons and options for the future. These lessons and options are essentially divided into two types. One set would continue the disputes over Aboriginality in Tasmania of the last ten years in an attempt to restrict community membership to a few well recognised lines of Aboriginal ancestry. The other encourages Aboriginal Tasmanians to think again of themselves as a nation, and opens up the possibility of somewhat broader community membership. Ultimately these lessons and options are concerned with the nature of the Aboriginal community in Tasmania rather than ATSIC elections per se. These and other elections have, in some ways, just been the sites for wider debates about the nature of the Aboriginal community in Tasmania. ${ }^{1}$

\section{The administrative and judicial context}

As noted above, all voting in ATSIC elections since 1990 has involved declarations of Indigeneity at the time of voting, which have been subject to both verification and challenge. For voters who turn up at polling booths, the verification and challenge mechanism has been controlled by Indigenous liaison officers, employed by the AEC, who use their personal knowledge and contacts in Indigenous communities to either confirm or investigate challenges to voters' declarations. For postal voters, the declaration verification mechanism was, in the 
early ATSIC elections, the signature of an office holder of an Indigenous organisation. However, in Tasmania in particular, this verification mechanism caused some level of concern.

A core group within the Tasmanian Aboriginal community, associated with the Tasmanian Aboriginal Centre (TAC), began to argue in the mid 1990s that the verification procedure for postal voters in ATSIC elections was too lenient and that some people whom they did not regard as part of the Tasmanian Aboriginal community might be voting. In the 1990 ATSIC election, 340 votes were cast in Tasmania. In 1993 the number of votes grew to 805, and in 1996 to 1,094. Of the votes cast in 1996, 647 (60\%) were cast as postal votes. In the rest of Australia, in that same election, just 2 per cent of votes were cast as postal votes. Under pressure from this core group within the Tasmanian Aboriginal community, the ATSIC Board of Commissioners increased the declaration verification requirements for postal voters for the 1999 ATSIC elections. Verification now required a statutory declaration and a letter of confirmation signed under the common seal of an Indigenous organisation. In Tasmania, under this more onerous administrative requirement, the total number of votes in 1999 dropped to 824 and postal votes to 345 , or 40 per cent of the total. ${ }^{2}$ Elsewhere in Australia in 1999, there were just 255 postal votes, or only about 0.5 per cent of total votes cast.

The core group within the Tasmanian Aboriginal community has also been concerned about the Indigeneity of some candidates in ATSIC elections. Reflecting these concerns, a person closely associated with the TAC, along with eight of the successful candidates in the 1996 ATSIC Tasmanian Regional Council election, launched a court challenge in the aftermath of that election. The case challenged the declarations of Indigeneity of eleven other candidates for the election, four of whom had been successfully elected. ${ }^{3}$ The onus of proof in the case was on the nine petitioners to show that the eleven challenged candidates were not Aboriginal or Torres Strait Islander for the purposes of the ATSIC Act. The Federal Court took until May 1998 to hand down its judgment.

The basis of the petitioners' case, citing Ryan's (1996) The Aboriginal Tasmanians and other published sources, was a fairly conventional rendering of Tasmanian colonial history in which all Aboriginal Tasmanians who had not been killed or died of disease during the earlier years of colonisation had been rounded up and removed to islands in Bass Strait by 1835. A small group was returned to the Tasmanian mainland at Oyster Cove in 1847, but only one of them, Fanny Cochrane-Smith, bore any children. The only other Aboriginal person living on mainland Tasmania at that time who bore children was, according to this history, Dolly Briggs-Johnson (or Dalrymple). ${ }^{4}$ So the petitioners argued that in order to be a contemporary Tasmanian Aboriginal person, one needed to trace ancestry either to the Bass Strait islands group, or to Fanny Cochrane-Smith or to Dolly Briggs-Johnson. Nine of the respondents traced their ancestry to some other person who, they claimed, was of Aboriginal descent. 
The Federal Court found that the petitioners had been successful in their challenge to only two of the eleven respondents. One of these two, Lance Lesage, had not been successful in his bid for election to the ATSIC regional council, and perhaps understandably had not bothered to appear at the court hearing or to file any evidence with the court in support of his Aboriginality. The other, Debbie Oakford, who had been elected, both appeared and presented documentary and oral evidence of her Aboriginality before the court. However, the court found Oakford's evidence of her Aboriginal descent unpersuasive at the point where she traced her ancestry to certain people of Aboriginal descent born in the 1840s and 1850 s, preferring instead the petitioners' evidence that Oakford's ancestors were people with similar common names who were not Aboriginal. Justice Merkel wrote:

Although I accept that Ms Oakford may genuinely believe that she has an Aboriginal ancestor, the petitioners have established for the purposes of the present case to the necessary standard of proof that she does not have Aboriginal descent (Edwina Shaw \& Anor $v$ Charles Wolf \& Orrs (1998) 389 FCA: 26). ${ }^{5}$

The judge went on to say that he accepted that Ms Oakford genuinely selfidentified as an Aboriginal person and that she enjoyed some community recognition as an Aboriginal person, but that in the absence of any Aboriginal descent, 'it must follow that she is not an Aboriginal person for the purposes of the [ATSIC] Act' (Shaw $v$ Wolf (1998) 389 FCA: 27). He declared that Oakford was 'not duly elected' as a regional councillor and that further counting of votes from the 1996 election be undertaken to determine the candidate entitled to be elected to the place for which Ms Debbie Oakford was returned' (Shaw $v$ Wolf (1998) 389 FCA: 47).

Perhaps of more importance was what this Federal Court judgment said in relation to the other nine respondents. Seven of these, like Oakford and Lesage, traced their Aboriginal ancestry to people outside the Bass Strait, CochraneSmith or Briggs-Johnson groups and so were similarly challenged by the petitioners who argued, essentially, that some person in each respondent's family tree who they thought was Aboriginal was in fact not. Justice Merkel spoke of the 'competing hypotheses' of the petitioners and respondents in relation to the respondents' ancestries and acknowledged many doubts and uncertainties in the historical records, both documentary and oral. But ultimately the judge argued, following the Briginshaw principle, that he should not 'lightly' prefer the hypotheses of the petitioners about ancestry over those of the respondents. ${ }^{6}$ In each case he found that the petitioners had not established, to the standard of proof required, that the respondent in question was not an Aboriginal person.

In the final two instances in this case, the respondent's tracing of their Aboriginal ancestry back to Dolly Briggs-Johnson was acknowledged by the petitioners and only community recognition and self-identification were disputed. However, in no case did the judge even look like accepting the petitioners' arguments about lack of community recognition and self-identification. His reasoning, in relation to all 
the respondents, was that these people genuinely self-identified as Aboriginal and that just because some people in the Aboriginal community did not know or recognise them as Aboriginal, others clearly did. All the respondents had some clearly recognised Aboriginal people who acknowledged them as Aboriginal, including, in two instances, one of the petitioners in the court case. ${ }^{7}$

The findings of this court case left three respondents on the Tasmanian ATSIC Regional Council in 1998 who did not trace their Aboriginal ancestry to the Bass Strait, Cochrane-Smith or Briggs-Johnson groups. In the judgment of the core group within the Tasmanian Aboriginal community, these findings were both incorrect and inadequate. The court case had, in their view, been a 'failure'. What is more, one of these three respondents from outside the central ancestry groups, John Clark, had been elected Regional Council Chairperson after the 1996 elections (see below).

One other interesting aspect of the 1998 Federal Court of Australia judgment was its final concluding observation:

It is unfortunate that the determination of a person's Aboriginal identity, a highly personal matter, has been left by a Parliament that is not representative of Aboriginal people to be determined by a Court which is also not representative of Aboriginal people. Whilst many would say that this is an inevitable incident of political life in Australia, I do not accept that that must always be so. It is to be hoped that one day if questions such as those that have arisen in the present case are again required to be determined that that determination might be made by independently constituted bodies which are representative of Aboriginal people (Shaw $v$ Wolf (1998) 389 FCA: 48).

I will return to this observation later, in discussion of the procedure for the trial Tasmanian electoral roll in 2002. But first it may be useful to provide a little more context to the electoral roll trial, emanating not from court cases or the existing administration of ATSIC elections, but from ATSIC electoral system reviews.

\section{ATSIC electoral system reviews}

Section 141 of the Aboriginal and Torres Strait Islander Commission Act 1989 (Cwlth) requires that after each round of ATSIC elections there be an electoral system review undertaken by a panel comprising the chairperson of ATSIC, representatives of the AEC and the Australian Survey and Land Information Group, and two Aboriginal or Torres Strait Islander persons who are not elected members of ATSIC.

After the 1993 ATSIC elections, this review panel noted widespread concern among Indigenous people that voting procedures meant that their votes were not secret. Those concerned wanted 'normal' voting, where intending voters could turn up at a polling booth, get their name ticked off and lodge their vote directly and anonymously in the ballot box, rather than placing their vote inside an envelope on which were written their name and declaration of Indigeneity. The review panel explained as follows: 
A significant factor in the formulation of the current system was the widespread resistance, in consultations some years ago, to the prospect of establishing a register of people eligible to vote in ATSIC elections ... Resistance was primarily based upon concerns about the uses to which such information would be put by members of the public or the government ...

Through its consultations, the Review Panel believes that the general attitude of the community concerning development of a register of voters has altered significantly over the time since previous consultations occurred. The overwhelming message being given to the Review Panel was that people would support the production of a register if it meant that 'normal' voting arrangements would then be possible (Aboriginal and Torres Strait Islander Elections Review Panel 1995: 6-7).

Accordingly, the review panel recommended the development of such a register through amendments to the ATSIC Act. But neither the government nor ATSIC took up this recommendation before the next round of ATSIC elections in 1996.

After the 1996 elections, the review panel noted that new declaration voting procedures, in which voter detail cards were separated from envelopes containing votes before lodgment of the latter in ballot boxes, had significantly overcome the perception that voting was not secret. However, they still noted 'strong and consistent support at consultation meetings' for a register of voters that would enable 'normal' voting. In addition they noted calls for a register emanating from Tasmania for a slightly different reason:

Two submissions called for a separate register of voters to be developed using the same process as that used to develop an electoral roll for Land Council elections in Tasmania, with the aim of determining eligibility (i.e. Aboriginality) to nominate and vote prior to the elections taking place. This would then ensure that all Regional Councillors are in fact Indigenous and would therefore obviate the need for litigation (Aboriginal and Torres Strait Islander Boundaries and Electoral Systems Review Panel 1997: 7).

Again the review panel recommended the development of a register of Aboriginal and Torres Strait Islander voters, this time specifying that it be done through empowering the AEC to establish a 'special elector category' within the CER.

The ATSIC Board of Commissioners did take up some of these concerns relating to Tasmania during that term and in September 1999 made a decision that:

Special conditions should apply to the ATSIC Regional Council elections, particularly in regard to Tasmania, to ensure that people who are not Aboriginal or Torres Strait Islanders are not able to vote in the elections (ATSIC Board Decision No. 2359).

The lateness of this decision within the term of the ATSIC Board meant that there was no time for changes to election rules to be made, specific to Tasmania, before the fourth round of ATSIC elections in late 1999. Electoral procedures were, in those elections, largely as in previous elections, although as noted previously there were increased declaration verification procedures for postal voters.

After the 1999 ATSIC elections, the electoral system review panel elaborated somewhat further on arguments being put to it in Tasmania: 
It was put to the Panel that the issue of the alleged non-Aboriginality of voters and Regional Councillors in Tasmania does nothing to enhance the community's perception of the election process or the credibility of ATSIC ...

This issue had been particularly strong in Tasmania over several review periods and has resulted in numerous legal petitions to the process. The Review Panel concludes that a pilot Indigenous electoral roll be trialed in Tasmania for the 2002 ATSIC elections (Aboriginal and Torres Strait Islander Boundaries and Electoral Systems Review Panel 2000: 8).

With this stipulation that the trial Indigenous electoral roll be restricted both to Tasmania and to the 2002 ATSIC elections, the idea was finally taken up both by the Commonwealth government and by the ATSIC Board. A methodology for the trial roll was developed by the ATSIC electoral unit, which was largely based on the model used for elections for the Aboriginal Land Council of Tasmania since 1995. This was approved by the ATSIC Board of Commissioners in June 2001. A secretariat for conducting the trial was soon after established within ATSIC's national administration, with the secretariat office in Tasmania deliberately kept separate from the established ATSIC regional office. Before proceeding to the details of the trial, however, it may be useful to give a little more demographic and political background to the situation in Tasmania.

\section{The political and demographic context}

Prior to the 1970s, Aboriginal affairs policy in Tasmania, as in other Australian states, was dominated by the State government. Most of that government's policy focus in the first half of the twentieth century had been on a reserve for Aboriginal people on Cape Barren Island in Bass Strait, proclaimed in 1912, and on the residents of that reserve (Ryan 1996: 239-47). From the late 1940s, under an emerging policy of assimilation, attempts had been made to close the reserve and encourage its residents to move to the Tasmanian mainland, and even to think of themselves no longer as Islanders or Aborigines (Ryan 1996: 247-51). At the end of this assimilationist, State-government dominated policy era, just 671 people in Tasmania identified as Indigenous in the 1971 national Census (see Table 1).

From the early 1970s, the Australian Commonwealth government began taking a far more active role in Indigenous affairs policy nationwide, and began promoting cultural pride among Indigenous people. It also, in the name of self determination or self management, encouraged the incorporation of Indigenous communitybased organisations for the conduct of community affairs and the delivery of certain Commonwealth-funded services such as legal aid. In Tasmania, the TAC, based in Hobart and Launceston, quickly emerged as the dominant new incorporated body representing the interests of Indigenous people state-wide. In this more conducive policy environment, the numbers of Tasmanians identifying in national censuses as Indigenous increased dramatically, and at faster rates than elsewhere in Australia, reaching over 6,000 by the mid 1980 s and over 13,000 by the mid 1990s (see Table 1). 
Table 1. Census counts and intercensal growth rates of people identifying as Aboriginal or Torres Strait Islander in Tasmania and the rest of Australia, 1971-2001

\begin{tabular}{lrccr}
\hline & \multicolumn{2}{c}{ Tasmania } & \multicolumn{2}{c}{ Rest of Australia } \\
\cline { 2 - 5 } Census Year & Count & $\begin{array}{c}\text { Intercensal growth rate } \\
\text { (\% per annum) }\end{array}$ & Count & $\begin{array}{r}\text { Intercensal growth } \\
\text { rate (\% per annum) }\end{array}$ \\
\hline 1971 & 671 & & 115,282 & 7.400 \\
1976 & 2,942 & 68.00 & 157,973 & -0.001 \\
1981 & 2,687 & -0.02 & 157,210 & 8.100 \\
1986 & 6,716 & 30.00 & 220,929 & 3.200 \\
1991 & 8,885 & 6.50 & 256,574 & 6.400 \\
1996 & 13,873 & 11.00 & 339,097 & 3.300 \\
2001 & 15,773 & 2.70 & 394,230 & \\
\hline
\end{tabular}

Source: ABS Census of Population and Housing 1971-2001.

In the 1970s and early 1980s, this growth through renewed identification was looked upon quite favourably by organisations such as the TAC, which could see its constituency growing. However later, as numbers increased still further, growth began to be seen as perhaps bringing the Tasmanian Aboriginal community into disrepute and possibly also as leading to competing centres of organisational and personal influence within that community, which was not necessarily to the benefit or liking of some of the more established personalities and organisational interests.

When ATSIC emerged at the beginning of the 1990s, the TAC and its leading spokesperson of previous years, Michael Mansell, were very critical of the new Commonwealth-initiated structure and Mansell declared that he would not be participating in it. He had for some years maintained the line that Aboriginal people had not ceded their sovereignty and did not recognise the sovereignty of the settler society (Ryan 1996: 277). As part of this approach Mansell refused to put himself on the CER, or to vote in Commonwealth or State elections. ${ }^{8}$ With ATSIC being a Commonwealth creation and the CER being used for ATSIC elections, Mansell's refusal to participate in ATSIC elections was essentially consistent with and a continuation of his earlier stand. Some others associated with the TAC and the core Tasmanian Aboriginal group also adopted Mansell's approach, so that the new Tasmanian ATSIC regional council structure was left somewhat open to those of more accommodating political methods. ${ }^{9}$

Some of those elected to the early Tasmanian ATSIC regional councils were clearly linked to the core Tasmanian Aboriginal community: for example, three Maynards were elected in 1990. But others elected had less well-known Aboriginal ancestries and family names. Also, with ATSIC funding, a significant number of new Aboriginal organisations emerged during the early 1990s, focusing on particular regions of Tasmania, or particular service types (Ryan 1996: 221). So the TAC and its spokespersons no longer enjoyed quite such a dominant position 
among the Tasmanian Aboriginal leadership. Indeed, three of the candidates whose Aboriginality was unsuccessfully challenged in the court case after the 1996 ATSIC elections had by then served for two full terms as ATSIC regional councillors, from 1990 to 1993 and 1993 to 1996. So the court case after the 1996 elections was, in some ways, a somewhat belated response by the TAC to the emergence, through the ATSIC regional council structure, of a new, alternative brand of elected Tasmanian Aboriginal leaders. When the court challenge 'failed', in only eliminating one of the elected new leaders and one other of the eleven respondents, the TAC became increasingly interested in the proposed Indigenous electoral roll as another way of achieving its desired ends. This was particularly so in the light of their experience of the roll system developed for a new State-government sponsored Aboriginal land council since 1996.

For the first election of the Aboriginal Land Council of Tasmania in 1996, 564 people applied to be on the roll. 174 of these were objected to and in 144 instances these objections were upheld by the Tasmanian government's Chief Electoral Officer, as advised by an Indigenous Advisory Committee of eight and the State Archivist, on the grounds that 'insufficient genealogical evidence' had been put forward in these cases to establish the applicant's Aboriginality. Hence the 1996 roll for the Aboriginal Land Council of Tasmania ended up with 420 people on it. When this exercise was repeated in 2001, 216 people applied, 53 were objected to and 33 of those objections were upheld by the Chief Electoral Officer, as advised again by the Indigenous Advisory Committee and the State Archivist. So the 2001 roll for the Aboriginal Land Council of Tasmania elections contained just 183 people. 10

Marianne Watson, one of the people excluded from the 2001 Aboriginal Land Council of Tasmania roll by the Tasmanian Chief Electoral Officer, appealed against that decision to the Tasmanian Supreme Court.11 Her appeal was unsuccessful, with the Chief Justice of the Supreme Court finding that:

There is no evidence of any family oral history from a known Aboriginal person and but little evidence of such a history connecting any ancestor of the appellant with an Aboriginal community (Aboriginal Lands Act 1995 in the Matter of Marianne Watson No. 2 (2001) 105 TASSC: 6)

On photographs of Watson's ancestors displaying 'Aboriginal facial characteristics and pigmentation', the Chief Justice essentially deferred to the eight-member Indigenous Advisory Committee, quoting an affidavit from one of the members of that Committee which stated that:

I recall having regard to the photographs which were part of Marianne Watson's submissions. It was my view and the view of the other members of the advisory committee that while there was a striking resemblance between the persons depicted and Marianne Watson, the photographs offered nothing by way of objective evidence to support Ms Watson's claim to be of Aboriginal descent. Neither I nor the other 
members of the committee concluded that the persons depicted appeared to be persons with Aboriginal ancestry (Watson No. 2 (2001) 105 TASSC: 11).

Clearly the core Aboriginal community in Tasmania had some success in 1996 and 2001 in objecting to between 15 and 30 per cent of applicants for the Aboriginal Land Council of Tasmania electoral roll. It was understandable therefore that they would want such a system extended to ATSIC elections.

In February 2002, the TAC came out in favour of the proposed electoral roll trial for the 2002 ATSIC elections, and indeed, for the first time, in favour of Tasmanian Aboriginals participating in ATSIC elections. Its press release read as follows:

The Tasmanian Aboriginal Centre, a long-time opponent of the Commonwealth Government's ATSIC Regional Council structure, has come out in support of voting in the ATSIC elections later this year.

State Secretary of the TAC, Trudy Maluga, said today, 'We have lobbied for years to stop white people voting in the Aboriginal elections for the Aboriginal and Torres Strait Islander Commission. After 10 years of struggle the Federal Government has agreed to a process developed in Tasmania which will test the bona fides of people wishing to vote in the ATSIC elections. Until now it has been impossible to stop white people voting just by claiming to be Aborigines. In this coming election Aborigines will be able to challenge white imposters and have Aboriginal people involved in deciding who is eligible to vote. This is the first time we as Aborigines have had a real chance to elect our own representatives for ATSIC.'

Miss Maluga, however, sounded a note of caution to Aborigines planning to vote: 'If Aborigines enrol to vote in these ATSIC elections that will automatically put them on the white electoral roll. Many Aborigines do not consider themselves part of the Australian nation and so have deliberately decided not to vote in white elections. The Government did not accept the TAC's argument that Aborigines should not have to be enrolled for white elections in order to vote in ATSIC elections-so any Aborigine who enrols for ATSIC now will no longer have the choice about voting in white elections.'

Miss Maluga said: 'We know ATSIC isn't perfect, but this ATSIC election is the best chance we've had in a long time for Aborigines to determine our own priorities. It means the Aboriginal community can come together to work in our own interests without the bickering caused by the white imposters who have dominated the ATSIC structure in Tasmania over the last decade' (Tasmanian Aboriginal Centre 2002).

This press release is notable for its softening of the TAC line on ATSIC, but also for its maintenance of some of the old line about Aboriginal people wanting to be able to chose not to enrol for Commonwealth and State elections as part of their non-recognition of settler sovereignty. It is also notable for labelling as white imposters' some of those who had dominated ATSIC structures in Tasmania over the previous decade. The TAC still clearly wanted to push out some of the people involved in recent ATSIC regional councils, as in the court case after the 1996 elections. Whether the trial ATSIC electoral roll would prove a means to that end, only time would tell. 


\section{The electoral roll trial}

The electoral roll trial for the ATSIC elections in Tasmania in 2002 began with a concerted public education campaign run by ATSIC and the AEC which included radio, television and newspaper advertising and visits to around 20 communitybased Aboriginal organisations. Enrolment commenced on 4 February 2002 and closed on 31 May, during which time 1,298 people applied for enrolment.12 Another public education campaign then advertised that the Provisional Roll, as it was now called, was available for public inspection through AEC service points around Tasmania, and that people over 18 years old could object to a particular individual being on the roll on the grounds that the applicant was not an Australian Aboriginal or Torres Strait Islander. At the close of the objection period on 28 June, 2,572 objections had been received to 1,128 applicants.

Clearly the Tasmanian Aboriginal community had become very animated and divided over these issues of Aboriginal identity in the context of the ATSIC electoral roll trial. Division was, in fact, deeper than I have thus far portrayed, since within the core community there were some who believed that only the Bass Strait islands ancestral group could claim genuine cultural continuity and that even among this group, once continuity was lost, it could not be reclaimed.13 Hence there were challenges lodged to the applications for enrolment not only for those outside the three core ancestral groups, but also to many within the Cochrane-Smith and Briggs-Johnson groups and even to some within the Bass Strait group. There were only 170 applicants for the ATSIC electoral roll to whom objections were not lodged.

The next step in the electoral roll trial was for the Commonwealth Minister to convene an Independent Indigenous Advisory Committee (IIAC) to consider the objections and either support or reject them. Under the model developed by the ATSIC electoral unit this was to be a nine-member committee with at least two members coming from each of the three ATSIC wards in Tasmania, in order to achieve some degree of geographic representativeness. Expressions of interest for being on this committee were called for in press advertisements in June, with 26 people indicating their interest. The nine selected by the Minister were announced early in July and met for the first time on 18 July 2002.

Two of the selected members of this IIAC were themselves the subjects of objections and these were dealt with first by the other seven members of the committee and dismissed. Over the next couple of months the nine members of the IIAC then looked at the cases of the other 1,126 applicants objected to, giving each the opportunity to submit material in support of their application. In its deliberations the Committee focused primarily on the issue of descent from an Aboriginal or Torres Strait Islander person, and was at times advised by an officer of the Tasmanian State Archives. No-one who convinced the Committee of their descent from an Aboriginal or Torres Strait Islander person was rejected on grounds of lack of community recognition or self-identification. However, as it emerged, the IIAC effectively adhered to a line, with only a few exceptions, that people had to show their decent from the Bass Strait, Cochrane-Smith or Briggs-

CENTRE FOR ABORIGINAL ECONOMIC POLICY RESEARCH 
Johnson groups. ${ }^{14}$ As a result, 674 applicants, or 60 per cent of those objected to, had objections to them upheld by the committee on the grounds that, on the balance of probabilities, they had not established their descent from an Aboriginal or Torres Strait Islander person. Applicants were informed of the decisions of the IIAC during the early weeks of September.

During August, when the IIAC was deliberating on the objections, the ABC's Four Corners current affairs program ran a story on the Tasmanian issue entitled Blackfella, Whitefella. The story contained much interesting material, including two Maynard brothers expressing resentment that 'fair-skinned kids' who had called them names like 'nigger' at school 30 or more years ago were now identifying as Aboriginal, setting up Aboriginal organisations, occupying jobs in them and 'doing the policies'. Another Maynard suggested that people associated with the TAC had 'shot themselves in the foot', in the early days, by accepting as members 'almost every Tom, Dick or Harry who walked through the door' and then in the 1990s saying to some of these people, including some who had been employees of the Centre, that they were no longer accepted as being members of the TAC. Four Corners also had February 2002 footage of Michael Mansell defending the ATSIC electoral trial saying that the 'whole idea' was to know before the elections that all candidates and voters were Aborigines and that this was 'fair, reasonable and appropriate'. 'Everbody', he noted, including himself, was open to challenge; though as the reporter noted in August 2002, Mansell had not himself applied to be on the roll, so was in practice not open to challenge.

Four Corners also gave considerable time to people who had put themselves on the roll and anticipated being challenged and possibly rejected by the IIAC. One of these was Debbie Oakford, who had been found by the Federal Court in 1998 not to be Aboriginal for the purposes of the ATSIC Act and had had her 1996 election to the Tasmanian ATSIC Regional Council overturned. Two others were John Clark and Brian Fisher, who had not only survived as respondents through the Federal Court case after the 1996 elections, but in Clark's case had been reelected again in 1999 not only as a Regional Council member, but also as Chairperson. Another such person was Kaye McPherson, spokesperson for the Lia Pootah community. This is a recently formed group of people who do not trace their ancestry to the Bass Strait, Cochrane-Smith or Briggs-Johnson families, but still claim descent from other Aboriginal individuals or, in some cases, from a suggested 'hidden' or 'lost tribe' of the Huon Valley. This latter suggestion was rejected in the Four Corners program by other more acknowledged historians, but defended by McPherson who, we were told, also refers to herself as a 'historical geographer'. When questioned about where, geographically, her own Aboriginal ancestry traced to, McPherson replied:

I've never really thought about it. No that's wrong. I can show you on a map, but it is really hard to verbalise. The area would be through New Norfolk, up through the midlands. Not the midlands so much as ... Oh, this is going to look really bad on telly ... It's interesting, because it's really hard. It's New Norfolk area, and that goes through to the east coast. But it also incorporated part of the Huon. But I only associate my ancestry with the Derwent Valley, not the Huon Valley. 
In chance conversations which I had with some members of the core group within the Tasmanian Aboriginal community shortly after the Four Corners program, they clearly thought that McPherson had indeed looked 'really bad on telly', and that they were finally winning the battle to rid the Tasmanian Aboriginal community, and ATSIC elections, of her kind. However, there was other important material in the Four Corners program, which I will return to later, which perhaps pointed in another direction.

Returning for now to the electoral roll trial itself, many of the 674 applicants who had objections to them upheld by the IIAC gave up their bid to be included on the ATSIC electoral roll at this point. However 131 of these applicants appealed to the Commonwealth's Administrative Appeals Tribunal (AAT). With hearing of these appeals set down for early October, the date of the ATSIC election in Tasmania was postponed from 19 October, as in the rest of the country, to 9 November. On 18 October, the AAT delivered a ruling which reversed the decisions of the IIAC in 130 of these 131 cases. This meant that the final roll for the 2002 ATSIC Tasmanian Regional Council election had 754 enrollees, or 58 per cent of the original 1,298 applicants.

In making the 18 October ruling, the AAT made some substantial comments both about the colonial history of Tasmania and about the issue of oral and documentary evidence of descent from Aboriginal ancestors. On colonial history, the AAT noted that while the descendants of Fanny Cochrane-Smith, Dolly Briggs-Johnson and 'the Bass Strait families' were all accepted as Aboriginal Tasmanians:

There is no reason to suppose that there are not a number of other lines of descent.

There was contact between the British and Europeans who came to Tasmania and the Aborigines right from the beginning. Not only did these foreigners seek out Aboriginal women [b]ut they were also assisted in achieving their purposes by Aboriginal men ... There was co-habitation between sealers, stock-keepers, timber getters and no doubt others with Aboriginal women. This was particularly so in the North West ... Undoubtedly these associations would have produced children. There are records of many Aboriginal children living with settlers. There was an orphan school at Hobart which was attended by Aborigines ... Aborigines of the half blood were released to the wider European community ... All in all it is really quite obvious that there must now be in Tasmania descendants from Aborigines who associated with the settlers between 1800 and 1876. The problem is how these persons can discover that line of descent in the absence of written records. To our mind there can be no doubt of the fact. The question is how persons can demonstrate such descent (Bruce Willam Patmore and Others $v$ Independent Indigenous Advisory Committee (2002) AAT: 10-11).

Scattered throughout this quoted passage were page references to Ryan (1996) The Aboriginal Tasmanians. Thus in promulgating this somewhat revisionist colonial history of Tasmania, with many more possibilities of Aboriginal descent, the AAT was referring extensively to the same published source to which the petitioners had referred in the court case after the 1996 election in putting 
forward their somewhat more conventional colonial history with its more restricted possibilities of Aboriginal descent.

On oral and documentary evidence, the AAT noted as follows:

The problem with archival evidence is that it can prove a line of descent but is unlikely to disprove it. Further, as we have already mentioned, archival evidence is not generally of assistance as to race. This is particularly so of a time when, as in the present case, indigenous persons were not awarded the same status as others and are therefore less likely to be recognised and identified in official records.

As we listened to applicant after applicant, day after day, outlining to us what they had been told by grandfathers and great grandfathers, aunts and great aunts, about their family history and tradition of aboriginality, followed usually by evidence of archival records and of the contents of births deaths and marriage registers, it became clearer and clearer to us that the really probative evidence of aboriginal descent was the oral histories and traditions and not the archival material. This evidence always seemed, according to the research and efforts of archivists, to point away from aboriginality. The credible family evidence we listened to day after day could not all be wrong. Indeed, it could not even mostly be wrong. In the end we decided that very little of it was wrong (Patmore $v$ IIAC (2002) AAT: 14).

Ironically, it was the AAT which was giving more credence to oral history and the IIAC which was relying more on the colonial government's archive. But given these general attitudes to oral evidence and colonial history, it was perhaps unsurprising that the AAT went on to reinstate so many of the appellants on the ATSIC roll.

Among those whom the IIAC would have had struck off the ATSIC roll, but who were saved by the AAT, were five respondents from the 1998 Federal Court case, including John Clark and Debbie Oakford. Clark and Oakford went on to be elected to the Tasmanian ATSIC Regional Council in November 2002, with Clark also being re-elected by the councillors as Chairperson in December 2002. Also among those whom the IIAC would have struck off the ATSIC roll, but who were saved by the AAT, were Kaye McPherson and Marianne Watson. Watson had, only a year before, had her claims of Aboriginality rejected by the State Indigenous Advisory Committee for the Aboriginal Land Council of Tasmania elections and by the Chief Justice of the Tasmanian Supreme Court. Now, however, her oral history of descent and photographs of ancestors showing Aboriginal-like features were accepted by the AAT. Watson and McPherson both stood as candidates in the 2002 Tasmanian ATSIC Regional Council elections, but were not elected. ${ }^{15}$

Viewed from the perspective of the group who wanted to rid ATSIC elections of the likes of Oakford, Clark, Watson and McPherson, the ATSIC electoral roll trial had changed, at this last turn through the AAT, from being a 'success' to being a 'failure'. For those reinstated by the AAT it had conversely changed, at this last turn, from being a 'failure' to being a 'success'. But beyond these very relativistic senses of success and failure, are there any more general lessons which can be gleaned from the Tasmanian ATSIC trial electoral roll experience and the years of dispute over Aboriginality in Tasmania which had preceded it? And what are the options for the future? 


\section{Lessons and options for the future}

At base, the conflict over Aboriginality in Tasmania is a dispute over the nature of colonial history and the contemporary Aboriginal community which arises out of that history. On one side are those who wish to see membership of that contemporary community restricted to the three acknowledged core descent groups. On the other side are those who see other broader possibilities for recognising Aboriginal descent. The 2002 ATSIC electoral roll trial was pushed for by, and looked during its early stages to be working in favour of, those arguing for restricted ancestry. The IIAC, while not explicitly adopting that criterion, was effectively excluding those from other descent groups (by upholding objections to their applications for enrolment). However, the AAT then took proceedings in precisely the opposite direction by clearly enunciating a view of Tasmanian colonial history which allowed for many other lines of Aboriginal descent.

Through the involvement of the AAT, the 2002 ATSIC electoral roll trial proved, in practice, an easier test for applicants and candidates from other lines of descent than the previous arrangements whereby voters could be challenged by Indigenous Liaison Officers and candidates could be challenged, after the elections, in the Federal Court. In relation to candidates, two reasons for this were that there were no Indigenous adversary parties in the AAT, as there were in the Federal Court after the 1996 elections, and the AAT only had limited time in which to remake the decisions of the IIAC. The AAT could, in practice, do no more than look quickly at the evidence of Aboriginal descent put before it by applicants, without contestation from other Aboriginal parties, and almost instantly make a decision on that basis. The Federal Court, by contrast, back in 1997-98, could take as much time as it wanted to decide and could also hear the point of view of the petitioners.

The lesson, or option, arising from the above discussion might be, at least in relation to candidates, to simply revert to the old arrangement of after-the-fact challenges in the Federal Court. At least then there would be proceedings in which both sides of a case could be put by different parties and there would be time for judges to decide. This, however, is unlikely to satisfy the protagonists within the Tasmanian Aboriginal community for more restricted definitions of possible lines of decent within that community. Recall that although the Federal Court in 1998 found that two of the respondents were not Aboriginal for purpose of the ATSIC Act, it also found that nine were, including seven whose claimed lines of ancestry were outside those of the Bass Strait, Cochrane-Smith and Briggs-Johnson groups. Justice Merkel of the Federal Court was, in that judgement, clearly siding with the view of Tasmanian colonial history which at least allowed for lines of Aboriginal descent other than these three. The only difference from the AAT was that Justice Merkel was able to test those claims of other lines of descent a little more actively and concertedly.

If Federal Court judges and AAT members seem consistently committed to a view of Tasmanian colonial history which allows for more possible lines of Aboriginal descent than the three established core groups, then perhaps the lesson or option 
arising from this realisation is to ask how issues of the interpretation of Tasmanian colonial history and consequent issues of Aboriginal identity arising from that history can be kept away from those sorts of decision makers. As noted above, Justice Merkel, in his closing remarks in 1998, supported the idea that issues of 'a person's Aboriginal identity' should be handled by 'independently constituted bodies which are representative of Aboriginal people' and not by nonIndigenous judges and parliaments. It would have been interesting to observe Justice Merkel's reaction had he found himself in the situation in which the AAT members found themselves in 2002, of having to review decisions about Aboriginal identity which an Indigenous representative body had already made. Would he have respected and followed the decisions of that body, or would he, like the AAT members, have felt some need to reconsider and remake the decisions on their original merits?

Interestingly, the Tasmanian Supreme Court Chief Justice who was faced with this dilemma in relation to the 2001 Aboriginal Land Council of Tasmania elections went further than did the AAT members in 2002 in respecting the decisions of the Indigenous representative body. Recall, from above, that the Chief Justice basically deferred to the affidavit of a member of the state Indigenous Advisory Committee rejecting Marianne Watson's photographic evidence, while the AAT members a year later accepted that evidence. The issue here would seem to be how much second guessing of Indigenous advisory or decision-making bodies should be engaged in by non-Indigenous judges or other decision makers. Should they question and revisit the Indigenous body's decision, or should they simply back these bodies and their decisions?

If the recent history of Indigenous advisory committees in Tasmania is anything to go by, such bodies in that State would probably end up rejecting between 15 and 50 per cent of all current applicants for Aboriginal elections. This would seem to be what is wanted by those within the core Tasmanian Aboriginal community who adhere to the restricted lines of descent view of Tasmanian Aboriginal identity. But such rejections would, of course, be at the cost and dissatisfaction of those who claim their Aboriginality through other lines of descent, who would clearly be significant in number. These people may not easily give up their claims to Aboriginality and so there is a possibility of ongoing conflict over Aboriginal identity in Tasmania, even if Indigenous representative bodies made decisions in the pattern of the last few years without non-Indigenous judicial or other oversight. It is also possible, over time, that these people claiming other lines of Aboriginal ancestry could obtain representation on Indigenous advisory committees and that the approaches of these committees could change accordingly. This is another option for the future that needs to be contemplated.

All the lessons and options for the future discussed above are built on the premise that the recent disputes over lines of descent and identity within the Tasmanian Aboriginal community can, in some way, be resolved and finalised. But the longer the disputes go on, unresolved by various attempted mechanisms, perhaps the more Aboriginal Tasmanians should be envisaging the possibility that these disputes simply cannot be resolved and finalised and that it may not

CENTRE FOR ABORIGINAL ECONOMIC POLICY RESEARCH 
be in the best interests of the Tasmanian Aboriginal community to prolong them. It may be better to walk away from the disputes and adopt a different approach to that of the last ten years.

Not being an Aboriginal Tasmanian myself, I am loath to offer advice to a people clearly recovering from a very difficult history and trying, in the process, to come to grips with their own personal and group identity. However, as a nonIndigenous academic social scientist who has been immersed in Australian Indigenous affairs issues over a 20-year period, and in this Tasmanian material for a more limited time, I feel some obligation to highlight some of the possible practical, strategic and theoretical problems of pursuing certain options. I will now turn, therefore, to what I see as some of the material in the Four Corners program which pointed away from the idea that the core group who have wanted to restrict possible lines of descent into the contemporary Tasmanian Aboriginal community were in fact winning their battle. This material, to my mind, points to the ultimate impossibility of winning this particular battle.

Long-time associate of Michael Mansell, Jim Everett, appeared on the Four Corners program saying that it was 'really the government' which had 'opened the door' of Aboriginal communities to new identifiers over the last 30 years. This I take to be a reference to the Commonwealth government's embracing of a more supportive and liberal view of Aboriginality and culture from the early 1970s. This policy has encouraged people to be proud of their Aboriginal heritage and effectively also to re-identify with it if, through some past conjunction of circumstances, they had stopped doing so. Everett went on in the Four Corners program to say, in general terms, that this 'opening of doors' into Aboriginal communities had to be stopped. The door could not, he argued, be left 'half open'. But despite this hard general rhetoric, when Everett was questioned about a specific case, that of Kaye McPherson, his approach softened and crumbled. Everett was not prepared to say whether McPherson is or is not Aboriginal, saying simply that he did not really know.

Elsewhere in the Four Corners program, ATSIC commissioner for Tasmania, Rodney Dillon, noted that if he sat down and thought about who was Aboriginal and who was not, he would 'become a very twisted man'. He noted that he had friends on all sides of the disputes and that, for the community, this was 'a pretty uncomfortable time'. He also noted that the IIAC had a very important and hard role to play and that he, personally, had tried to stay away from issues of identity and instead 'stick to culture and issues like that'.

This was the same Rodney Dillon who, as a successful candidate in the 1996 ATSIC elections, was one of nine petitioners to the Federal Court seeking to have eleven other candidates struck out as not being Indigenous. As noted above, some of the petitioners in that case actually vouched for the Aboriginality of some of the respondents, and here we see Dillon, on Four Corners, publicly saying that he does not want to get involved in such identity issues. So there is reason to believe that the petitioners in the case after the 1996 elections were not entirely united in their views, either as to who among the respondents were or were not Aboriginal 
or as to why, precisely, they were pursuing the court case. Dillon, for one, was perhaps somewhat reluctantly drawn into the case as a petitioner.

Dillon's and the other petitioners' positions seem somewhat like Everett's. All seem to be able to say confidently, in general, that access to Aboriginal identity and community membership should be restricted, or closed. But in particular cases they are unable to say categorically, or reach agreement with other members of the already recognised community, that particular individuals who are claiming Aboriginality definitely are or are not Aboriginal. What seems a reasonable general proposition to restrict community membership falls away in the face of the impossibility of making determinations in relation to particular individuals.

One other particular case which intrigues me, as a political scientist, is that of John Clark, elected ATSIC regional councillor since 1990 and regional council chairperson since 1996. Clark clearly had support among some of the eight 1996 elected regional councillors who were petitioners in the Federal Court case, and has maintained a degree of support among both voters and other regional councillors since, despite having ancestry which is outside the three core recognised groups. This case too suggests an indeterminacy and uncertainty among the core family groups about who they should and should not accept as members of the community.

The central practical, strategic and theoretical problem for the clearly recognised core members of the Tasmanian Aboriginal community would seem to be how to achieve unanimity and certainty among themselves in judgments about who should be included and who excluded. Without such unanimity and certainty, which the last ten years of disputes would seem to suggest cannot be achieved, the strategy of excluding people and restricting community membership simply will not work. So, are there other possible lessons and options for the future which may open up from this perspective? Again, I think, the Four Corners program included some interesting material which, at least potentially, did show another way forward.

Four Corners included historical footage of Michael Mansell, Jim Everett and others setting off for Libya in 1987, travelling on Aboriginal passports. As noted earlier, Mansell was inclined, at that time, to point out that Aboriginal people had never ceded their sovereignty and did not recognise the sovereignty of the settler society. He talked of an Aboriginal nation which still had the right to govern itself and which might one day possibly want to treat, or negotiate some terms of settlement, with the settler nation. For these and other purposes, Mansell and others had even established an Aboriginal Provisional Government, a potent symbol of Aboriginal nationhood. Jim Everett, at the time, wrote an article entitled 'Aboriginal Nationhood' in which he talked about possible procedures for 'nationalising' people who wanted to 'immigrate' from the 'Australian nation' to the 'Aboriginal nation' (Everett 1987).

Nations are, importantly, somewhat different, conceptually, from groups whose membership is based on descent. They are political communities in which lines of 
descent may have some role to play in determining membership. However, as Everett recognised in 1987, there are generally also other criteria for membership of nations. These other criteria may include being born and living on an ongoing basis in a particular territory, migrating to a particular territory and expressing some ongoing commitment to the political community of that territory, or marrying into the political community as a spouse of one of its members. In short, nations are somewhat open and elastic political communities of people in a way in which descent groups are not.

Everett, Mansell and the TAC were, I would argue, more on the right track in the 1980s, when they thought of Aboriginal Tasmanians as a nation and when they were more welcoming in their acceptance of new members of the TAC than they have been since. Nations can and do grow, through people wanting to join them. And while few nations adopt a completely 'open-door' policy, healthy tolerant nations do generally accommodate significant growth without losing their sense of distinctive historical origins or contemporary common purpose. So another option for the future for core members of the Tasmanian Aboriginal community, it seems to me, would be to embrace people with more tenuous Aboriginal ancestral connections who want to become part of the contemporary Tasmanian Aboriginal community and to project that attitude, to the larger Australian and world communities, as the sign of a healthy, vibrant, active and adaptive contemporary Tasmanian Aboriginal nation. This option, both theoretically and strategically, clearly points in a very different direction from those which seek to continue the disputes of the last ten years which have tried to restrict membership of the Tasmanian Aboriginal community to just the descendents of the three recognised ancestral groups.

\section{Conclusion}

This paper began as an attempt to examine what might seem like a relatively simple administrative development relating to ATSIC elections-the development of a trial electoral roll within the CER for Indigenous people in Tasmania. Through exploring the various contexts and the results of this trial, however, the focus of the paper has broadened to a consideration of the nature of the contemporary Aboriginal community in Tasmania and its relationship to various renderings of Tasmanian colonial history.

The last 30 years have clearly been a very difficult time for the Aboriginal community in Tasmania, born in many ways of their renewed recognition by both State and Commonwealth governments. While such recognition was withheld, the identifying community was quite small and its public face focused on a few committed activists, like Michael Mansell. When renewed recognition was forthcoming, by contrast, identification clearly became far more attractive to a much larger number of people. While the more long-standing Aboriginal identifiers at the core of the Tasmanian Aboriginal community, and some nonIndigenous people, each have their own legitimate reasons for being somewhat cynical about these processes of renewed identification, it may well not be in the 
long term interests of the Tasmanian Aboriginal community to greatly probe and dispute these processes.

In the latter part of this paper, I have identified possible lessons from the Tasmanian electoral roll trial and options for the future. Some of these options relate to a scenario in which the disputes over Tasmanian Aboriginal identity of the last ten years might be continued. But the final identified option points in a very different direction, both strategically and theoretically. It points to thinking again of Aboriginal Tasmanians as a nation, as promoted by Michael Mansell and Jim Everett in the 1980s. Without seeking to recommend particular options, I would certainly, as a political scientist, commend this final option for further thought and debate.

\section{Notes}

1. A subsequent paper, with John Taylor, will build on earlier work and explore issues of participation and representation in the 2002 ATSIC elections nationwide. See Sanders, Taylor and Ross (2000a, 2000b).

2. The AEC advises that the introduction of wards into the Tasmanian ATSIC electoral system arrangements in 1999 may also have affected voter numbers.

3. There were in total 34 nominations for 12 positions on the Tasmanian ATSIC Regional Council at this election. So there were another 15 unsuccessful candidates who did not have their declarations of Aboriginality challenged.

4. As I understand it, the first surname (Briggs) was acquired during infancy and the second (Johnson) through marriage. Dalrymple was in fact Dolly's given name, but became used in the broader community as a surname. She is most commonly referred to in written sources as Dolly Dalrymple. However, through comments made by one of her descendants on earlier drafts of this paper, I was made aware that it is now seen as preferable to refer to her as Dolly Briggs-Johnson.

5. As well as being reported directly by the Federal Court of Australia (FCA), this case is also reported at 83 Federal Court Reports: 113 and at 163 Australian Law Reports: 205.

6. Being a civil court proceeding, the standard of proof required was on the balance of probabilities, However, the Briginshaw principle, as explained by Judge Merkel is that in 'cases involving serious allegations, such as criminal conduct, fraud or moral wrongdoing', the court 'should not lightly make a finding that, on the balance of probabilities, a party to civil litigation has been guilty of such conduct' (Shaw $v$ Wolf (1998) 389 FCA: 10).

7. These two instances were not the acknowledged descendants of Dolly Briggs-Johnson. So they were examples of someone within the core ancestral groups clearly vouching for the Aboriginality of someone from outside those groups.

8. Enrolment and voting in Commonwealth elections had only been made compulsory for Aboriginal people in 1984. From 1962 until then, enrolment for Commonwealth elections had been voluntary for Aborigines, though once enrolled voting was compulsory (see Sanders 2001). The Tasmanian State electoral legislation has never, to my knowledge, had specific provisions relating to Aboriginal people's right to vote. 
9. I am informed that there was a TAC meeting at the time which passed a resolution suggesting that people not participate in ATSIC.

10. These relatively small numbers seeking to be on the Aboriginal Land Council of Tasmania roll, compared to those voting in ATSIC elections, can be explained in a number of ways. First the Aboriginal Land Council of Tasmania was known to have a remit largely limited to the holding and management of particular small parcels of land, whereas ATSIC's remit is much larger, including in the order of $\$ 6 \mathrm{~m}$ being available for the funding of projects and services undertaken by community-based organisations. Second, having destroyed the 1996 roll, the Tasmanian Electoral Office in 2001 had to start again from scratch in constructing the Aboriginal Land Council of Tasmania roll and it deliberately adopted a low key approach to publicising the process. The Tasmanian Electoral Office did not see its role, second time round, as actively promoting the Aboriginal Land Council of Tasmania enrolment process among Aboriginal Tasmanians.

11. Watson had been an elected member of the 1990-93 Tasmanian ATSIC Regional Council.

12. In light of Michael Mansell's past approach, it would have been interesting to know how many of these were new additions to the CER and how many were existing enrollees who simply wanted their Indigeneity identified. The AEC advices that, although records were not kept in this way, it is thought that a 'considerable majority' were existing enrollees who simply wanted their Indigeniety identified.

13. An article in The Sunday Tasmanian of 7 April 2002 summarised this rather extreme attitude as follows: 'To be a Tasmanian Aborigine, you-and each generation before you back to tribal days-must have claimed to be Aboriginal'. It quoted Aboriginal Legal Service Officer Ricky Maynard as saying: 'There can be no break in the link of a person's connection with the Aboriginal community'.

14. The exceptions included a few people whose Indigenous ancestry was from outside Tasmania in other parts of Australia.

15. See note 11 .

\section{References}

Aboriginal and Torres Strait Islander Boundaries and Electoral Systems Review Panel 1997. Review of Electoral Systems: A Report to the Minister for Aboriginal and Torres Strait Islander Affairs, ATSIC, Canberra.

- 2000. Review of Electoral Systems: A Report to the Minister for Aboriginal and Torres Strait Islander Affairs, ATSIC, Canberra.

Aboriginal and Torres Strait Islander Elections Review Panel 1995. Review of Electoral Systems: A Report to the Minister for Aboriginal and Torres Strait Islander Affairs, ATSIC, Canberra.

Everett, J. 1987. 'Aboriginal Nationhood' Pugganna News, 26, September.

Ryan, L. 1996. The Aboriginal Tasmanians (2nd edn), Allen \& Unwin, St Leonards, NSW [1st edn University of Queensland Press, 1981].

Sanders, W., Taylor, J. and Ross, K. 2000a. 'Participation and representation in ATSIC elections: A ten year perspective', CAEPR Discussion Paper No.198, CAEPR, ANU, Canberra. 
Sanders, W., Taylor, J. and Ross, K. 2000b. 'Participation and representation in ATSIC elections: A ten year perspective', Australian Journal of Political Science, 35 (3): 493513.

Sanders, W. 2001. 'Delivering democracy to Indigenous Australians: Aborigines, Torres Strait Islanders and Commonwealth electoral administration', in M. Sawer (ed.), Elections: Full, Free and Fair, Federation Press, Sydney.

Tasmanian Aboriginal Centre 2002. 'Tasmanian Aboriginal Centre supports new ATSIC voting procedures', Press release, 28 February.

\section{Case law}

Aboriginal Lands Act 1995 in the Matter of Marianne Watson No. 2 (2001) 105 Tasmanian Supreme Court.

Bruce William Patmore and Others $v$ Independent Indigenous Advisory Committee (2002) Administrative Appeals Tribunal, General Administrative Division, Hobart, 18 October.

Edwina Shaw \& Anorv Charles Wolf \& Ors (1998) 389 Federal Court of Australia. 



\section{Centre for Aboriginal Economic Policy Research Publications}

\section{For information on earlier CAEPR Discussion Papers and Research Monographs please contact:}

Publication Sale, Centre for Aboriginal Economic Policy Research, The Australian National University, Canberra, ACT, 0200, Telephone: 02-6125 8211, Facsimile: 02-6125 2789. Information on CAEPR, and abstracts or summaries of all CAEPR print publications and those published electronically, can be found at the following WWW address: http://online.anu.edu.au/caepr/

\section{MONOGRAPH SERIES}

7. Mabo and Native Title: Origins and Institutional Implications, W. Sanders (ed.), 1994.

8. The Housing Need of Indigenous Australians, 1991, R. Jones, 1994.

9. Indigenous Australians in the Economy: Abstracts of Research, 1993-94, L.M. Roach and H.J. Bek, 1995.

10. Native Title: Emerging Issues for Research, Policy and Practice, J. Finlayson and D.E. Smith (eds), 1995.

11. The 1994 National Aboriginal and Torres Strait Islander Survey: Findings and Future Prospects, J.C. Altman and J. Taylor (eds), 1996.

12. Fighting Over Country: Anthropological Perspectives, D.E. Smith and J.D. Finlayson (eds), 1997.

13. Connections in Native Title: Genealogies, Kinship and Groups, J.D. Finlayson, B. Rigsby and H.J. Bek (eds), 1999.

14. Land Rights at Risk? Evaluations of the Reeves Report, J.C. Altman, F. Morphy and T. Rowse (eds), 1999.

15. Unemployment Payments, the Activity Test and Indigenous Australians: Understanding Breach Rates, W. Sanders, 1999.

16. Why Only One in Three? The Complex Reasons for Low Indigenous School Retention, R.G. Schwab, 1999.

17. Indigenous Families and the Welfare System: Two Community Case Studies, D.E. Smith (ed.), 1999.

18. Ngukurr at the Millennium: A Baseline Profile for Social Impact Planning in South East Arnhem Land, J. Taylor, J. Bern and K.A. Senior, 2000.

19. Aboriginal Nutrition and the Nyirranggulung Health Strategy in Jawoyn Country, J. Taylor and N. Westbury, 2000.

20. The Indigenous Welfare Economy and the CDEP Scheme, F. Morphy and W. Sanders (eds), 2001.

21. Health Expenditure, Income and Health Status among Indigenous and Other Australians, M.C. Gray, B.H. Hunter and J. Taylor, 2002.

22. Making Sense of the Census: Observations of the 2001 Enumeration in Remote Aboriginal Australia, D.F. Martin, F. Morphy, W.G. Sanders and J. Taylor, 2002. 


\section{RECENT DISCUSSION PAPER SERIES}

225/2001 Building Indigenous learning communities, R.G. Schwab and D. Sutherland.

226/2001 Sustainable development options on Aboriginal land: The hybrid economy in the twenty-first century, J.C. Altman.

227/2002 The Indigenous population of Cape York Peninsula, 2001-2016, J. Taylor and M. Bell.

228/2002 Urban CDEPs as Indigenous Employment Centres: Policy and community implications, M. Champion.

229/2002 Three years on: Indigenous families and the welfare system, the Kuranda community case study, R. Henry and D.E. Smith.

230/2002 Towards an Indigenous order of Australian government: Rethinking selfdetermination as Indigenous affairs policy, W. Sanders.

231/2002 Population futures in the Australian desert, 2001-2016, J. Taylor.

232/2002 Autonomy and the Community Development Employment Projects scheme, W.S. Arthur.

233/2002 Jurisdictional devolution: Towards an effective model for Indigenous community self-determination, D.E. Smith.

234/2002 Indigenous community stores in the 'frontier economy': Some competition and consumer issues, S. McDonnell and D.F. Martin.

235/2002 Some competition and consumer issues in the Indigenous visual arts industry, J.C. Altman, B.H. Hunter, S. Ward and F. Wright.

236/2002 Indigenous residential treatment programs for drug and alcohol problems: Current status and options for improvement, M. Brady.

237/2002 Journey without end: Reconciliation between Australia's Indigenous and settler peoples, W. Sanders.

238/2002 Decentralisation, population mobility and the CDEP scheme in central Cape York Peninsula, B.R. Smith.

239/2002 Welfare and the domestic economy of Indigenous families: Policy implications from a longitudinal survey, A. Daly, R. Henry and D. Smith.

240/2002 Estimating the components of Indigenous population change, 1996-2001, Y. Kinfu and J. Taylor.

241/2002 Reforming indigenous welfare policy: Salutary lessons and future challenges for Australia from the US experience, A. Daly and D.E. Smith.

242/2002 Philanthropy, non-government organisations and Indigenous development, R.G. Schwab and D. Sutherland.

243/2003 Options for benchmarking ABS population estimates for Queensland Aboriginal and Torres Strait Islander communities, J. Taylor and M. Bell.

244/2003 Creating a sense of 'closure': Providing confidence intervals on some recent estimates of Indigenous populations, B.H. Hunter and M.H. Dungey. 


\section{WORKING PAPER SERIES}

Available at no cost on WWW at http://online.anu.edu.au/caepr/

3/1999 Dealing with alcohol in Alice Springs: An assessment of policy options and recommendations for action, M. Brady and D.F. Martin.

4/1999 Aboriginal people in the Kakadu region: Social indicators for impact assessment, J. Taylor.

5/1999 Reforming the Northern Territory Land Rights Act's financial framework into a more logical and more workable model, J.C. Altman and D.P. Pollack.

6/2000 Governance and service delivery for remote Aboriginal communities in the Northern Territory: Challenges and opportunities, N. Westbury and W. Sanders.

7/2000 What's in it for Koories? Barwon Darling Alliance Credit Union and the delivery of financial and banking services in north-west New South Wales, N. Westbury.

8/2000 The relative social and economic status of Indigenous people in Bourke, Brewarrina and Walgett, K. Ross and J. Taylor.

9/2001 Indigenous communities and business: Three perspectives, 1998-2000, J.C. Altman.

10/2001 Indigenous Australian arrest rates: Economic and social factors underlying the incidence and number of arrests, B.H. Hunter.

11/2001 Sensitivity of Australian income distributions to choice of equivalence scale: Exploring some parameters of Indigenous incomes, B.H. Hunter, S. Kennedy, and D.E. Smith.

12/202 Indigenous Australians and competition and consumer issues: An interim review of the literature and an annotated bibliography, J.C. Altman, S. McDonnell, and S. Ward.

13/2002 The rise of the CDEP scheme and changing factors underlying Indigenous employment, B.H. Hunter.

14/2002 Institutional factors underpinning Indigenous labour force participation: The role of the CDEP scheme and education, B.H. Hunter.

15/2002 Generating finance for Indigenous development: Economic realities and innovative options, J.C. Altman.

16/2002 The spatial context of Indigenous service delivery, J. Taylor.

17/2002 The potential use of tax incentives for Indigenous businesses on Indigenous land, O. Stanley.

18/2002 Banking on Indigenous Communities: Issues, options, and Australian and international best practice, S. McDonnell and N. Westbury.

19/2002 One size fits all?: The effect of equivalence scales on Indigenous and other Australian poverty, B.H. Hunter, S. Kennedy and N. Biddle. 